\title{
Pendidikan Anak Usia Dini Di Indonesia: Permasalahan Kurikulum Taman Kanak Kanak
}

\author{
Yulianti Dwi Astuti
}

Universitas Islam Indonesia

\begin{abstract}
Absract
The early childhood years are important because in this period all developmental aspects (physical, emotional, and intellectual) grow at their fullest pace. Unfortunately, parents, society and government (through their school system) in indonesia show a lack of awareness on the importance of giving appropriate early stimulation (formal and also non formal) to children at this age. As a result, treatment to children, in their learning and growing process, tend to be developmentally inappropriate. The current paper tries to examine the importance of giving developmentally appropriate leaming environment in kindergarten. The length of the school is only one dimension of the kindergarten experience. Other important issues include the nature of the kindergarten curriculum and the quality of teaching. Changing the length of the hours spent in kindergarten is not as important as making sure that all kindergarteners are provided with developmentally and individually appropriate learning environment. Developmentally appropriate kindergarten classroom must have one thing in common: the focus will be on the development of the child as a whole.
\end{abstract}

Keywords: early childhood, kindergarten curriculum

\section{Pendahuluan}

Dembangunan bangsa merupakan suatu proses yang berkelanjutan, sehingga pernbangunan tidak akan berhenti padı suatu generasi saja. Ini berarti bahwa setiap generasi memiliki tugas untuk terus melanjutkan pembangunan yang telah dilakukan oleh generasi sebelumnya. Untuk itu maka kualitas sumber daya manusia harus ditingkatkan sedini mungkin sehingga dapat diharapkan anak-anak kelak dapat menjadi generasi penerus yang lebih berkualitas.

Usia di bawah lima tahun (balita) adalah usia yang paling kritis atau paling menentukan dalam pembentukan karakter atau kepribadian seseorang. Perkembangan inţeligensi juga hampir seluruhnya terjadi pada usia di bawah lima tahun dimana pada usia ini anakanak memiliki inteligensi laten (potential in- telligence) yang luar biasa. Anak-anak usia belia memiliki bermilyar-milyar sel syaraf otak yang sedang berkembang dan memilkki kernampuan serta daya memori yang kuat. Menurut Dirjen PLSP Depdiknas Fasli Jalal (Pikiran Rakyat, 8 Januari 2004) sel-sel otak yang terus dirangsang akan semakin cepat berkembang, semua synap synap akan mengental dan otak menjadi berfungsi. Anak yang jarang mendapat rangsang atau stimulasi bisa mengakibatkan terputusnya syaraf-syaraf otak. Ini dapat berbuntut pada tidak berfungsinya otak secara sempurna.

Pada umumnya kita selalu menyalahkan anak-anak apabila țingkah laku mereka tidak seperti yang kita inginkan. Kalau anak tidak bisa menangkap pelajaran dikatakan bodoh. Kenyataannya hal ini lebih banyak di- 
sebabkan karena kurangnya pengetahuan dan pemahaman orang tua terhadap perkembangan jiwa anak sehingga perlakuan yang diberikan kepada mereka menjadi kurang tepat.

Anak-anak memiliki rasa ingin tahu yang luar biasa dan kemampuan untuk menyerap. informasi yang sangat tinggi. Kebanyakan orang tidak mengenali dan memahami kemampuan "magic" yang ada pada anak íni. Mereka hanya bisa berkata, "Saya tahu anakanak belajar lebih cepat", tetapi mereka tidak tahu seberapa cepat anak-anak bisa belajar.

Umumnya orang siap mengorbankan waktu bertahun-tahun dan uang berjuta-juta rupiah untuk menyekolahkan anaknya di perguruan tinggi, tetapi sebaliknya orang kurang memperhatikan pendidikan anakanak pada usia dini. Fenomena tersebut menggambarkan bahwa kesadaran masyarakat akan pentingnya pendidikan anak usia dini perlu ditingkatkan dan dibina. Menurut laporan hasil analisis Tim Education for All (2001), pada tahun 2000 lebih dari 80 persen dari sekitar 26 juta anak Indonesia usia 0-6 tahun belum mendapatkan layanan pendidikan dini. Khusus pada anak yang berusia 4-6 tahun yang berjumlah sekitar 12 juta orang, baru terlayani sekitar 2 juta orang di taman kanak-kanak (TK) atau raudhatul athfal (RA).

Kondisi tak jauh berbeda dipaparkan dalam Indonesia Educational Statistics in Brief 2000/2001 yang dikeluarkan oleh Badan Penelitian dan Pengembangan (Balitbang) Depdiknas. Disebutkan dari 26,17 juta anak berusia $0-6$ tahun baru 7,16 juta $(27 \%$ ) yang terlayani pendidikannya melalui berbagai satuan pendidikan usia dini. Perinciannyaa: 2,53 juta anak $(18,74 \%$ dari 13,5 juta) usia $0-$ 3 tahun terlayani melalul Bina Keluarga Balita (BKB), 4,63 juta anak (36,54\% dari 12,67 juta) usia 4-6 tahun terlayani antara lain melalui taman kanak-kanak 1.583 .500 anak, raudhatul athfal 390.400 anak, kelompok bermain 4.800 anak, tempat penitipan 9200 anak, dan SD di atas 6 tahun sebanyak 2.641 .300 anak.
Hingga Maret 2002, jumlah TK di Indonesia hanya ada 48.000 buah. Itupun yang berstatus negeri hanya 112 buah, sisanya (sekitar 99\%) dimiliki oleh lembaga swasta dengan kondisi dan mutu yang beragam. Jika dibandingkan dengan Malaysia, pada tahum 2000 saja hampir $90 \%$ anak usia dini dapat mengikuti pendidikan TK. Adiningsih (Suara Pembaharuan Daily, 30 Januari 2003) menuliskan, tampaknya krisis ekonomi yang terjadi di Indonesia juga ikut mempengaruhi hal ini, seiring dengan kian mahalnya biaya masuk TK dari tahun ke tahun sehingga menyulitkan orang tua untuk mengikutsertakan anaknya dalam pendidikan anak usia dini.

\section{Masa Peka Belajar}

Selama ini sebagian masyarakat masih menganggap bahwa anak usia dini belum waktunya untuk belajar. Jika belajar diartikan dengan sekolah dimana anak harus duduk tenang, mendengarkan uraian guru, disibukkan dengan tugas, maka anggapan tersebut bisa jadi benar sebab anak usia dini belum dapat diminta duduk tenang dan paham akan makna tugas. Namun bila belajar diartikan dengan menyerap informasi sebanyak mungkin, anggapan di atas menjadi salah total. Menurut Hurlock (1997), perkembangan intelektual anak yang sangat pesat justru terjadi pada usia 0-6. Selama dalam kandungan, susunan syaraf yang tumbuh cepat adalah jumlah dan ukuran sel syaraf. Cortex (lapisan tebal kelabu yang membentuk permukaan luar otak) anak terdiri dari 100 milyar neuron dan sekitar satu triliun sel glia yang berfungsi sebagai sambungan. Setelah dilahirkan pertumbuhan sel syaraf lebih diarahkan pada pengembangan sel yang belum berkembang. Tidak lama setelah dilahirkan, otak bayl menghasilkan triliunan sambungan antar neuron yang jumlahnya melebihi kebutuhan. dalam perkembangan. Setelah anak berusia 4 tahun pertumbuhan susunan syaraf berlangsung sedikit lebih lambat.

Menurut Vander, Sherman \& Luciano 
(2001), ketika lahir, ada bagian-bagian cortex yang belum memiliki fungsi. Bagian inilah yang memungkinkan manusia untuk belajar. Melalui persaingan alami, sambungan-sambungan yang tidak atau jarang digunakan akan mengalami pemutusan sambungan. Sementara itu pernantapan sambungan akan terjadi apabila neuron mendapatkan informasi dan mampu menghasilkan letupan-letupan listrik. Disinilah letak penting stimulasi rangsangan sensorik yang berasal dari mata, telinga, hidung, mulut, maupun perabaan.

Hasil penelitian Dr. Mark R Rozenzweig dari fakultas Psikologi Universitas California memperlihatkan bahwa stimulasi atau pernberian rangsangan di masa kecil bisa mengubah ukuran dan fungsi kimiawi otak. Makin banyak rangsangan yang dikirim, makin besar pula kemampuan otak untuk berfungsi secara cerdas. Sebaliknya, kurangnya rangsangan lingkungan atau stimulus psikososial akan membuat ukuran otak menjadi lebih kecil 20-30\% dibandingkan ukuran normal anak seusianya (Suara Merdeka Cybernews, 21.8.2004).

Pendidikan anak usia dini (PAUD) ini semakin terasa urgensinya bila mengingat adanya batasan waktu dimana sel-sel otak tidak lagi dapat digiatkan dengan mudah. Bloom, pimpinan American Educational Research Association menyebutkan 50\% dari potensi inteligensi anak sudah terbentuk di usia 4 tahun, kemudian mencapai $80 \%$ ketika ia berusia 8 tahun. Setelah umur 8 tahun, tanpa melihat lingkungan dan bentuk pendidikan yang diperoleh, kemampuan kecerdasan anak hanya dapat diubah sebanyak $20 \%$. Di sisis lain, perubahan paling besar dari kemampuan mental juga terjadi saat otak mengalaml pertumbuhan pesat. Semakin bertambah umur, pertumbuhan otak semakin menurun dan akhirnya mencapai kestabitan pada usia 17 tahun.

Dengan potensi yang ada padanya, Hurlock (1994) mengatakan bahwa masa usia dini merupakan periode keemasan dalam proses perkembangan anak. Di usia ini anak mengalami lompatan kemajuan yang luar biasa, baik dalam hal fisik, emosional maupun sosial sehingga sangat berpotensi untuk belajar. Oleh karena itu, sangat disayangkan apabila proses pembelajaran anak usia dini kurang diperhatikan. Blla masa peka ini lewat, akan sulit atau bahkan tidak mungkin lagi untuk melakukan jenis pembelajaran tersebut. Akibatnya anak akan mengalami kerugian sepanjang hidupnya.

Upaya Melakukan Pendidikan Anak Usia Dini Arti penting pendidikan anak usia dini telah menjadi perhatian internasional. Dalam pertemuan Forum Pendidikan Dunia tahun 2000 di Dakar Senegal dlhasilkan 6 kesepakatan sebagai kerangka aks। pendidikan untuk semua (The Dakar Framework for Ac(ion Education for $A l$ ) yang salah satu butirnya menyatakan untuk memperluas dan memperbaiki seluruh perawatan dan pendidikan anak usia dini, terutama bagi anak-anak yang sangat rawan dan kurang beruntung. Terkait dengan hal tersebut, tanggal 19 April 2001 dibentuklah Direktorat Pendldikan Anak Usia dini di bawah Ditjen Pendidikan Luar Sekolah dan Pemuda, Departemen Pendidikan Nasional.

Upaya pertama yang harus dilakukan adalah menumbuhkan kesadaran pada sernua pihak (orangtua, guru, peme-rintah) bahwa anak usia dini pun memiliki hak atas pendidikan. Mereka bertanggung jawab mengoptimalkan perkembangan anak, baik inteligensi, kecerdasan emosi, moral maupun kecerdasan spiritualnya. Menurut Beck (1998), lingkungan dapat meningkatkan atau menurunkan taraf kecerdasan anak. Hal ini dibuktikan dalam proyek Head-Start yang berlangsung 8 minggu. $\mathrm{IQ}$ anak-anak setelah proyek ini selesai nalk antara 6-14 angka. Jadi kecerdasan anak dapat ditIngkatkan jika dilakukan dengan cara dan saat yang tepat. Oleh karena itu anggapan yang telah berkembang di tengah masyarakat bahwa pendidikan anak tidak terlalu penting keberadaannya perlu diluruskan.

Gutama, Direktur Pendidikan Anak Usia dini Departemen Pendidikan Nasional 
mengatakan bahwa Depdiknas mempunyai program untuk mengadakan sosialisasi PAUD karena hingga saat ini diakui masih terdapat sejumlah kebingungan dan ketidaktahuan sebagian masyarakat tentang batasan, arti penting, den pemahaman tentang PAUD. Selain itu, sejurnlah sekolah bagi anak usia dini mulai play group, kepompong dan sebagainya terkesan mahal dan hanya bisa dijangkau masyarakat kelas atas saja. Kesan eksklusif ini perlu dihilangkan di tengahtengah masyarakat. Untuk itu Direktorat PAUD tengah mengembangkan sebuah kurikulum PAUD yang dinamai Acuan Menu Pembelajaran Generik yang memberikan rincian tentang metode pernbelajaran untuk anak usia 0-4 tahun.

Pasal 28 Undang Undang Republik Indonesia Nomer 20 tahun 2003 Tentang Sistem Pendidikan Nasional menyebutkan bahwa Pendidikan Anak Usia dini diselenggarakan sebelum jenjang pendidikan dasar (usia 0-6 tahun). Pendidikan ini dapat diselenggarakan melalui jalur pendidikan formal, non formal, dan/atau informal. Pendidikan melalui jalur pendidikan formal berbentuk Taman Kanak-kanak (TK), Raudhatul Athfal, atau bentuk lain yang sederajat. Pendidikan non formal berbentuk Kelompok Bermain (KB), Taman Penitipan Anak (TPA), atau bentuk lainnya. Pendidikan informal berbentuk pendidikan keluarga atau pendidikan yang diselenggarakan oleh lingkungan.

Tujuan Pendidikan Anak Usia dini adalah untuk memberikan pembinaan terhadap upaya pelayanan pendidikan anak usia dini agar anak dapat tumbuh dan berkembang secara optimal sesuai tahap tumbuh kembang dan potensi masing-masing anak. Ada pun program PAUD yang menjadi binaan Direktorat PAUD meliputi:

\section{Taman Penitipan Anak.}

Taman penitipan anak adalah bentuk layanan PAUD bagi anak usia 0-6 tahun yang juga berfungsi sebagai wahana kosejahteraan atau pengasuhan anak sebagai pengganti sementara peran or- ang tua atau keluarga selama ditinggal bekerja atau sebab lain.

2. Kelompok bermain

Kelompok bermain adalah layanan

PAUD bagi anak usla 3-6 tahun yang berfungsi untuk membantu meletakkan dasar-dasar ke arah pergembangan sikap, pengetahuan dan ketrampilan yang diperlukan bagi anak usia dini dalam menyesuaikan diri dengan ling. kungannya serta untuk pertumbuhan dan perkernbangan selanjutnya.

3. Satuan PAUD sejenis

Satuan PAUD sejenis adalah bentukbentuk layanan PAUD lainnya yang tidak diselenggarakan delam bentuk Tarnan Penitipan Anak atau kelompok bermain. Satuan PAUD sejenis dapat berbentuk PAUD dalam keluarga dan berbagai leyanan pendidikan lain yang bersifat umum maupun khusus.

4. Pemberdayaan peran serta masyarakat Pemberdayaan peran serta masyarakat adalah usaha pengembangan sumber potensi masyarakat guna meningkatkan pengetahuan, kemampuan, ketrampilan, dan sikap peran serta masyarakat dalam pengelolaan (perencanaan, pengorganisasian, pelaksanaan, pembinaan, pengawasan dan evaluasi) berbagai penyelenggaraan program pembangunan.

Untuk upaya sosialisasi PAUD, Mulyadi (Media Indonesia online, 2003.) menilai perlunya pemberdayaan lembaga-lembaga yang selama ini cukup intens dengan keberadaan anak usia dini tersebut. Lembaga seperti posyandu, RT/RW, dan penitipan anak dibentuk sedemikian rupa sehingga menjadi salah satu wadah pembinaan PAUD. Mulyadi juga mengatakan bahwa dalarn pendidikan anak usia dini masyarakat jangan sampai terjebak pada institusi. Stimulasi awal pendidikan anak menurut Mulyadi justru seharusnya diberikan dalam situasi alamiah yang akan memungkinkan anak untuk terstimulasi secara optimal. Orangtua 
memainkan peranan penting dalam pendidikan anak usia dini. karena itu orang tua dan masyarakat perlu disiapkan untuk membina anak usia dini.

Taman Kanak-kanak Sebagai Jalur Formal PAUD

Istilah taman kanak-kanak (kindergarten) dikemukakan oleh Friedrick Froebel pada tahun 1840 (Santrock, 1994). Taman kanakkanak secara harafiah berarti taman untuk anak-anak. Friedrick me-nyatakan bahwa seperti halnya tanaman yang sedang tumbuh, anak-anak memerlukan perawatan secara hati-hati.

Elkind (1987) seorang pakar psikologi perkembangan mengatakan bahwa orang tua yang mempunyai kemampuan dan dedikasi, serta mempunyai waktu dan energi dapak mempersiapkan pendidikan anak-anak di rumahnya. Apabila orangtua mempunyai kemampuan dan sumber-sumber yang tersedia bagi anak-anak agar dapat bereksplorasi dalam berbagai jenis pengalaman belajar, dan memungkinkan anak-anak maupun orang dewasa lain di sekitar rumahnya untuk bermain secara ekstensif dengan anak-anak, maka sekolah taman kanakkanak tidaklah diperlukan.

Berawal dari tahun 1980-an d Amerika, program pengajaran di TK mengalami banyak modifikasi. Saiah saku yang kemudian dikenal iuas di kota-kota besar di Indonesia sejak tahun 1990-an adalah program TK full day. Jika jadwal sekolah TK tradisionai (half day) seliap harinya berkisar jam 08.00-10.00/ 11.00. TK full day memiliki jadwal sekolah yang lebih panjang, yaitu dari jam 08.00 sampai dengan 14.30/15.00.

Meningkatnya jumlah orangtua yang keduanya bekerja dan kenyataan bahwa kebanyakan anak menghabiskan sebagian besar waktunya di luar rumah merupakan perubahan yang terjadi pada masyarakat indonesia sekarang ini. Perubahan ini berpengaruh pada semakin populernya taman kanak-kanak dengan program full day. Orangtua yang kesulitan untuk mencari taman kanak-kanak dan tem pat pengasuhan anak selama mereka bekerja biasanya sangat tertarik pada program full day ini.

Sampai saat ini para ahll masih berbeda pendapat tentang kedua jenis program ini. Sebagian ahli menyatakan bahwa program reguler lebih baik karena berbagai alasan, sebaliknya ahli lain menyatakaan bahwa program full day memberikan lebih banyak keuntungan bagi anak daripada program iradisional. Oleh karenanya, penyeienggara pendidikan TK pun masih menawarkan kedua jenis program ini.

Secara umum ada beberapa hal yang menyebabkan TK dengan program fill day dalam sepuluh tahun belakangan ini semakin menarik perhatian orangtua, antara lain;

a. Meningkatnya jumlah orangtua yang bekerja kedua-duanya

b. Meningkatnyajumlah anak yang memiliki pengalaman di play group/ daycare, sehingga anak terblasa dengan kegiatan di luar rumah, menghabiskan wakku lebih banyak dengan teman sebayanya

c. Meningkatnya kemampuan anak untuk menyesuaikan diri dengan kehidupan d luar rumah

d. Meningkatnya pengaruh TV dan mobilitas keiuarga sehingga anak lebih "peka" terhadap dunia

e. Perubahan pandangan orang tua tentang persiapan akademik untuk keberhasilan anak di sekolah yang lebih lanjut.

Bagaimanapun juga, masing-masing program tentu memiliki kelebihan dan kekurangan. Herman (1984) menggambarkan secara detil kelebihan dari program fill day. Dia percaya bahwa dalam program full day suasana lebih rileks dan tidak dikejar-kejar waktu. Waktu sekolah yang panjang juga memungkinkan anak untuk mengalami lebih banyak hal di sekolah, selain itu kualitas interaksi guru dan murid juga menjadi lebih baik sehingga guru lebih mudah untuk mendeteksi dan menangani masalah belajar yang potensial ada pada anak.

Di lain pihak program full day juga 
memiliki kelemahan antara lain; biayanya mahal karena membutuhkan lebih banyak staf pengajar dan asisten untuk menciptakan rasio guru-murid yang memadai, membutuhkan ruang kelas yang lebih banyak (karena tidak dimungkinkannya sistem shift), kadangkala ada program full day yang terlalu berorientasi akademik dan mengajarkan ketrampilan-ketrampilan dasar pada anak sebelum waktunya, atau sebaliknya, program full day juga bisa jadi hanya mirip day-care sehingga tidak ada nilai lebih yang dapat diperoleh anak.

Para ahli yang berpandangan bahwa program half day lebih baik mengemukakan kelebihan program half day yaitu: biayanya relatif lebih terjangkau, kualitas pendidikan lebih baik karena guru dan murid tidak kelelahan di sekolah, memberikan cukup pengalaman sosial bagi anak sembari mempersiapkan mereka untuk memasuki tahap sekolah selanjutnya, less probability of stress karena waktu sekolah memperhatikan attention span, level of interest dan home ties. Waktu belajar di sekolah yang tidak terlalu lama juga memberikan kesempatan bagi anak untuk lebih banyak bermain dan berinteraksi dengan orangtua dan anak sebayanya dalam lingkungan yang tidak formal (Filkenstein, 1983)

Adapun kelemahan program half day diantaranya adalah dibutuhkannya penyesuaian dirí anak untuk melakukan pergantian kegiatan di tengah hari dan juga kesempatan untuk memperoleh manfaat dari aktivitas tambahan atau aktivitas lapangan sangat kecil karena jam sekolah yang pendek.

Stinard (1982) merangkum hasil dari berbagai penelitian yang membandingkan antara program half daydan program full day. Disimpulkan bahwa ada hubungan yang positif antara keikutsertaan anak dalam TK full day dengan prestasi belajar di sekolah dasar. Stinard juga menemukan bahwa siswa SD kelas 1 yang berasal dari TK full day berprestasi minimal sebaik siswa TK half day pada setiap mata pelajaran (dan dalam penelitian lainnya siswa yang berasal dari TK foll day berprestasi lebih baik). Penelitian longitudinal Humprey (1983) df Ohio mengindikasikan bahwa siswa kelas 4 SD yang berasal dari TK full day masih mempertahankan kelebihan mereka dibanding siswa dari program half day.

Cryan, et.all (1992) melaporkan hasil studi longitudinalnya terhadap anak-anak yang mengikuti program full day dan half day sebagai berikut;

a. Siswa TK full day memperlihatkan kemandirian, keterlibatan di kelas, produktivitas kerja, dan prestasi belajar yang lebih baik dibanding siswa TK half day

b. Siswa TK full dayjuga lebih mudah untuk dekat dengan guru, memperlihatkan withdrawal, kemarahan, perasaan malu, dan perilaku menyalahkan yang lebih sedikit dibandingkan siswa TK haff day

c. Secara umum, anak-anak TK $f$, day memperlihatkan perilaku yang lebih positif dibanding para murid di program TK half day:

Dari tahun ke tahun minat orang tua untuk menyekolahkan anaknya di TK full day semakin meningkat. Penyelenggara pendidikan taman kanak-kanak juga seakanakan berlomba untuk membuka program-program full day. Riset menyatakan bahwa bagaimana anak-anak TK menghabiskan waktu mereka adalah lebih penting dibanding jumlah waktu yang dihabiskan anak-anak di sekolah. Dengan kata lain, waktu belajar di taman kanak kanak full day yang tidak disertai aktivitas yang tepat tidak akan menghasilkan kelebihan pendidikan apapun dibanding program taman kanak kanak half-day yang tradisional.

Kurikulum Dan Pengajaran Taman Kanak Kanak yang Sesuai Untuk Anak Usia dini

Taman Kanak-kanak di Indonesia adalah suatu tahap dalam pendidikan anak yang tidak menjadi prasyarat untuk memasuki tahap pendidikan selanjutnya (Penjelasan 
pasal 28 Undang Undang Republik Indonesia Nomer 20 tahun 2003 Tentang Sistem Pendidikan Nasional). Program pendidikan taman kanak-kanak yang ada saat ini sangatlah bervariasi. Beberapa sekolah taman kanak-kanak mungkin lebih menekankan pada perkembangan sosial, sementara yang lain lebih menekankan perkembangan kognitif (Suprapti, 1999). Bahkan beberapa pakar meyakini bahwa sebagian pendidikan taman kanak-kanak dewasa ini sarat dengan orientasi pada pencapaian prestasi (Santrock, 1994). Suatu orientasi yang lebih mengedepankan "nama baik" sekolah yang dibebankan terlalu dini pada anak-anak.

Para ahll psikologi perkembangan anak telah lama mempercayal peran penting permalnan di dalam pengajaran anak-anak. Idealnya, pendidikan di TK harus disesuaikan dengan tahap perkembangan anak agartidak menjadi beban bagi siswa. Bermain bagi anak, menurut Semiawan (Pikiran Rakyat, 8 Januari 2004) adalah suatu kebutuhan. Dengan merancang pelajaran TK untuk dilakukan sambil bermain, maka anak dapat belajar sesuai tuntutan perkembangannya. Pelaksanaan pendidikan TK yang melupakan kebutuhan bermain anak dikatakan Semiawan sebagai pendidikan yang salah kaprah dan perlu diluruskan.

Dari pengalaman sehari-hari dengan anak-anak, guru maupun orang tua dengan mudah dapat melihat bahwa permainan spontan adalah suatu cara alami bagi anak dalam belajar. Pengamatan atas permainan anak-onak mengungkapkan bahwa permainan dapat menjadi wadah yang luas dan mendalam untuk semua wilayah perkembangan anak, baik fisik, emosional, sosial, dan intelektual.

Belajar melalui penyelidikan spontan (pengamatan dekat, percobaan, dan pemeriksaan) bagi anak-anak sama alaminya dengan permainan spontan. Banyak observer sudah mencatat bahwa anak-anak usia dini adalah ahli antropologi dan itmuwan alami. Energi mereka seolah-olah tak ada habisnya untuk mempelajari semua aspek yang menyangkut kulturtempat mereka dilahirkan, bahasa, cerita, musik, dan literatur. Mereka memeriksa dengan seluruh akal sehat dan ketrampilan yang dibutuhkan. Apakah suatu hal sesuai atau tidak, darimana hal-hal datang, apa arti keberadaan mereka, bagaimana mereka dibuat, serta bagaimana panutan dan orang dewasa bereaksi terhadap mereka. Kurikulum dan metode pengajaran yang sesuai untuk anak usia dini adalah kurikulum yang memasukkan dorongan dan aktivitas anak-anak usia dini untuk melakukan penyelidikanpenyelidikan tersebut dan menonjolkan pentingnya emosi dan perasaan individu anakanak di dalam kelompok.

Karakteristik anak-anak usia dini menuntut suatu kurikulum yang melibatkan suatu variasi dan keseimbangan aktivitas yang dapat disiapkan dalam bentuk konteks proyek bekerja (Katz dan Chard, 1989). Sebagai contoh, anak-anak taman kanak kanak dapat melakukan proyek di mana mereka memeriksa suatu peristiwa rill. Selama proyek seperti itu, anak-anak akan mempelajari huruf, kemampuan matematika, kemampuan bicara serta ketrampilan mendengarkan dan memperoleh kata-kata baru selagi mereka membagi bersama hasil penemuan mereka dengan orang rain.

Suatu kurikulum yang baik (Katz and Chard, 1989) menyediakan aktivitas-aktivitas berikut:

1. Studi topik yang terintegrasi, bukannya instruksi-instruksi untuk melakukan ketrampilan tertentu pada seluruh anak

2. Peluang bagi anak-anak untuk belajar dengan mengamati dan mengadakan percobaan dengan objek riik

3. Keseimbangan antara aktivitas yang dilakukan atas inisiatlf anak dan guru

4. Peluang bagi anak untuk melakukan permainan spontan dan melakukan aktivitas yang difasilitasi guru

5. Proyek kelompok dimana kerjasama dapat terjadi secara ala mi

6. Bidang aktivitas yang menuntut penggunaan otot kecil dan besar 
7. Pengenalan literaturyang baik dan musik yang terkait dengan kultur đ kehidupan anak-anak dan kultur lain yang diwakili oleh masing-masing anak di dalam kelas

8. Penilaian murni terhadap tiap kemajuan perkembangan anak

9. Peluang untuk anak-anak dengan latar belakang dan tingkatan perkembangan yang bebeda untuk mengambil bagian di seluruh aktlvitas kelompok

10. Waktu untuk individu atau kelompok kecil untuk bertemu guru guna mendapat bantuan yang spesifik dalam memperoleh dasar membaca, menulis, matematika, dan ketrampilan lain jika dibutuhkan.

Suatu tantangan utama untuk sekolah yang peduli dengan penggunaan terbaik dari waktu anak-anak di taman kanak kanak adalah menetapkan pengajaran dan aktivitas pembelajaran yang penuh arti. Program TK yang sesuai dengan tahap perkembangan anak setidaknya harus memenuhi syaratsyarat berikut: Pertama, menggabungkan pelajaran baru dengan pengalaman masa lalu melalui tugas-tugas yang mencakup beragam kemampuan dan pengelompokan beragam usia dalam situasi yang santai. Kedua, melibatkan anak-anak dalam mengalami secara langsung dan melakukan interaksi informal dengan objek, anak-anak lain, dan orang dewasa. Ketiga, menekankan pengembangan bahasa dan pengalaman preliteracy (persiapan belajar membaca) sesuai tahap perkembangan anak.

Selain itu, program tersebut harus memperhatikan pula kerjasama dengan orangtua untuk berbagi Informasi tentang anak-anak mereka, membangun suatu pemahaman tentang peran guru dan orang tua, menekankan kebiasaan membacakan buku untuk anak-anak di sekolah dan di rumah, dan menetapkan langkah untuk kerjasama lebih lanjut antara orang tua dan guru. Penawaran aktivitas yang melibatkan kelompok kecil, kelompok besar dan aktivitas individual secara seimbang menjadi syarat selanjutnya. Sebagai tambahannya ke-majuan siswa melalui pengamatan guru dan pengujian, serta pengumpulan sistematis dari tugas-tugas siswa harus dilaksanakan. Terakhir, mengembangkan ketrampilan sosial anak-anak, mencakup juga strategi resolusi konflik.

National Association for the Education of Young Children (NAEYC) menyarankan para orang tua untuk terlibat aktif dalam memilih sekolah bagi anaknya. Guna memudahkan orang tua dalam menilai apakah suatu TK baik atau buruk bagi perkembangan anaknya NAEYC menyarankan orangtua untuk memperhatikan indikasi-indikasi seperti: Anakanak menghabiskan sebagian besar waktu mereka untuk bermain dan belajar dengan material atau anak-anak yang lain. Mereka tidak mengeluyur tanpa tujuan, dan mereka tidak diharapkan untuk duduk dengan tenang untuk periode waktu yang lama. Selain itu, anak-anak mempunyai akses untuk berbagai aktivitas sepanjang waktu belajar. Anak-anak tidak diharuskan untuk melakukan hal yang sama pada waktu yang sama. Guru bekerja dengan anak-anak secara individual, dalam kelompok kecil, dan keseluruhan kelompok pada waktu berbeda sepanjang hari. Mereka tidak menghabiskan seluruh waktu mereka dengan keseluruhan kelompok. Sekolah yang memberi stimulasi tepat sesuai perkembangan biasanya juga menyediakan kelas yang dihias dengan hasil karya asli anakanak, tulisan mereka sendiri dengan ejaan asli, dan cerita-cerita yang didiktekan oleh anak-anak ke guru. Anak-anak mempelajari angka-angka dan abjad dalam konteks pengalaman sehari-hari mereka. Mereka juga mengerjakan tugas-tugas lapangan dan mempunyai waktu (sedikitnya satu jam) untuk bermain dan bereksplorasi. Worksheets digunakan sedikit/tidak sama sekali. Selanjutnya anak-anak mempunyai kesempatan untuk bermain di luar setiap hari. Permainan di luar tidak pernah dikorbankan untuk kegiatan yang bersifat instruksional. Guru membacakan buku pada anak-anak secara individual atau dalam kelompok kecil sepanjang hari, tidak hanya pada waktu cerita 
kelompok.

Untuk itu kurikulum disesuaikan untuk mereka yang cepat menangkap dan juga untuk mereka yang memerlukan bantuan tambahan. Guru mengetahui bahwa pengalaman dan latar belakang yang berbeda pada anak-anak berarti bahwa mereka tidak mempelajari hal yang sama pada waktu yang sama dengan cara yang sama. Sehingga anak-anak dan orang tua mereka selalu menanti-nanti saat untuk berangkat sekolah. Orang tua merasa aman mengirimkan anaknya ke sekolah. Anak-anak senang untuk datang ke sekolah, mereka tidak menangis/berteriak secara terus menerus atau mengeluh merasakan sakit jika akan berangkat sekolah.

\section{Pembahasan}

Pendidikan anak usia dini tidak boleh dianggap sepele dan diabaikan. Bahkan pendidikan bayi sejak nol tahun (baru lahir) atau bahkan sejak bayi masih dalam kandungan sudah saatnya dikembangkan untuk mempersiapkan generasi penerus yang tebih berkualitas. Guru-guru dan fasilitas terbaik semestinya diprioritaskan pada lembaga pendidikan anak usia dini.

Dedikasi yang tulus dari guru dan dukungan serta kerjasama sepenuhnya dari orangtua akan menjamin keberhasilan pendidikan anak-anak. Pendidikan anak usia dini tidak boleh hanya mengandaikan pada pendidikan formal di sekolah, peran serta orangtua dan masyarakat sangat diperlukan untuk menciptakan pendidikan non formal maupun informal bagi anak usia dini yang dapat dijangkau semua pihak.

Panjang pendeknya waktu sekolah hanyalah salah satu aspek dari pendidikan d TK, masalah yang lebih penting adalah tentang kurikulum dan kualitas pengajaran yang diberikan. Secara umum jika kurikulum disesuaikan dengan tahap perkembangan anak dan mampu memberi stimulasi yang baik, maka apapun program pendidikan yang dipilih (half day atau full day) untuk mendidik anak usia dini tidak menjadi masalah.

\section{Daftar Pustaka}

Adiningsih, N.U. 2003. Krisis Ekonomi Hancurkan Anak Indonesia. Suara Pembaharuan Daily (on-line). www suuaㅁagembahaharuan $\mathrm{com} / \mathrm{ne}$ w! 2003/01/30/Editorledio 3 htm

Beck, J. 1999. How to Raise a Brighter Child. New York: Simon \& Schuster Inc.

Cryan, J. 1992. Successful Outcomes of Full Day Kindergarten: More Positive Behavior and Increased Achievement in Years After. Early Childhood Research Quarterfy 7(2): 187-203.

Dakar Framework for Action Education for All. 2000. Education For All: Meeting Our Collective Commitments. hitp: Iwww2 2 , unes cQ, grglwefle n- con It dakframeng, shtm/29/12/03

Elkind, D. 1987. Miseducation: Preescholers at Risk. New York: Knoft.

Filkenstein, J.M. 1983. Result in Midwestern University Professors Study: Kindergarten Scheduling. http:Lwww. kidsource.com $29 / 12 / 03$

Herman, B.E. 1984. The Case for The Al Day Kindergarten. Bloomington: Phi Delta Kappa Educational Foundation

Hurlock, E.B. 1994. Psikologi Perkembangan: Suatu Pendekatan Sepanjang Rentang Kehidupan (edisi 5). Alih bahasa: Istiwidayanti \& Soedjarwo. Jakarta: Erlangga

Hurlock, E.B. 1997. Perkembangan Anak (Edisi 6). Alih bahasa: Tjandrasa \& Zarkasih. Jakarta: Erlangga 
Kartz, L.G, Chard, S.D .1989. Engaging Children's Minds: The Project Approach. Norwood: Ablex Publishing Corporation.

Krelzmann, S. 2004. Early Childhood: What are the Advantages and Disadvantages? (on-line). http: $/ \underline{w} \underline{w} \underline{w} \underline{w}_{t}$ dp state.wi노오

Media Indonesia On-line, 2003. PAUD Perlu Mendapat Prioritas. http:Lwww.

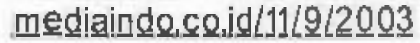

National Association for the Education of Young Children. 2004. 10 Signs of a Great Preschool (on-line). http:/l www naeyc.orgldefaㅁ닌.htm.

Pikiran Rakyat. 2004. PendidikanAnak-anak Sudah" "Salah Kaprah", 8 Januari 2004

Santrock, J.W. 1994. Child Development. Dubuque: Brown \& Benchmark.

Stinard, TA. 1982. A synopsis of Research on Kindergarten Scheduling: half Day, Everyday Fun Day. Aftemate Day; and
Full Day, Every Day

Suara Merdeka Cybernews. 2004. Tips Membangkitkan Potensi Anak. http:ll

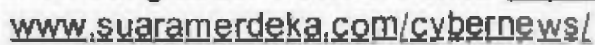
waaita/tips 3, htm!

Suprapti, V. 1999. Psikologi Perkembangan Anak Usia Pra-Sekolah dan Implikasinya Pada Pendidikan. Anima, Indonesian Psychological Joumal. Volume 15 No 1. Oktober 1999. Fakultas Psikologi Universitas Surabaya

Undang Undang Republik indonesia Nomor 20 tahun 2003 Tentang Sistem Pendidikan Nasional. Pasal 28 (1-6) tentang Pendidikan Anak Usia Dini. Jakarta: Djambatan IKAPI

Vander,A., Sherman, J.Luciano, D., 2001. Human Physiology: The Mechanism of Body Function. New York: Mc Graw Hill Companies, Inc.

Zaporozhets, A.V., Elkonin, D.B. 1974. The Psychology of Preschool Children. Massachusetts: Williams Grapic Service Inc. 